\title{
GEOCHEMICAL CHARACTERIZATION OF SATELLITE HYDROCARBON FORMATIONS IN PRINOS-KAVALA BASIN (NORTH GREECE)
}

\author{
Kiomourtzi P. ${ }^{1}$, Pasadakis N. ${ }^{2}$, and Zelilidis A. ${ }^{3}$ \\ ${ }^{I}$ Kavala Oil S.A., paschalia.kiomourtzi@kavalaoil.gr \\ ${ }^{2}$ Technical University of Crete, Department of Mineral Resources Engineering, \\ pasadaki@mred.tuc.gr \\ ${ }^{3}$ University of Patras, Department of Geology, a.zelilidis@upatras.gr
}

\begin{abstract}
Conditions favoring generation, migration and trapping of hydrocarbons generated economically significant reservoirs in Prinos-Kavala Basin. Prinos oil field and South Kavala gas field are characteristic examples. The submarine fan packed the basin during Upper Miocene. The hydrocarbons were accumulated in turbidites, deposited in a strongly reducing environment, with high sulfur concentration. Evaporates are also deposited before and after the turbidite system.

In this study, which is part of a doctorate thesis, extracts retrieved from cored samples of two satellite formations in Prinos-Kavala Basin, Epsilon and Kalirahi, selected at the "Prinos equivalent" formations, have been analyzed, using geochemical methods, and found to exhibit common compositional characteristics. The analysis of biomarkers indicates that the bitumens are immature and non-biodegraded, while their origin is considered mainly algal, with minor terrestrial contribution. Variations on characteristic geochemical ratios between formations, such as $\mathrm{Pr} / \mathrm{Ph}$, $T_{s} / T m$, oleanane/hopane and steranes index, are attributed to differences on the type of organic mater input, or the depositional setting of sediments. The identification of the organic matter type, the hydrocarbons generation, migration paths and traps of each structure within the basin is vital for the evaluation of a reliable model of the basin and further hydrocarbon exploration in North Aegean basins.
\end{abstract}

Key words: Turbidite, Biomarker, North Aegean.

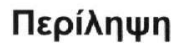

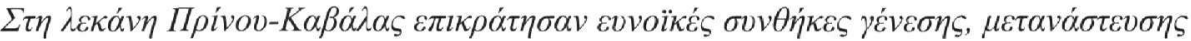

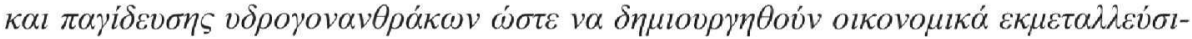

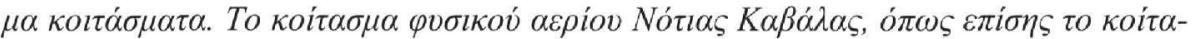

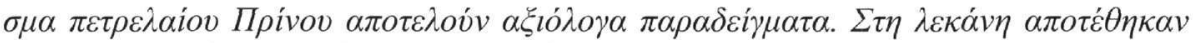

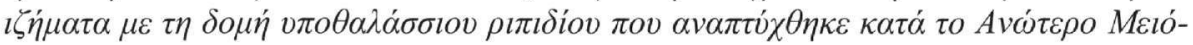

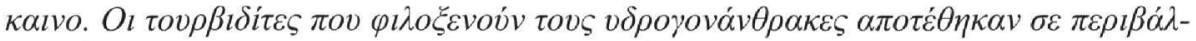

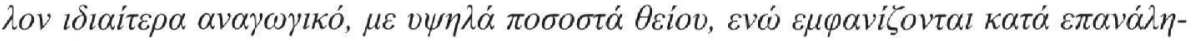

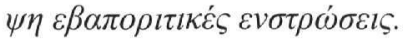




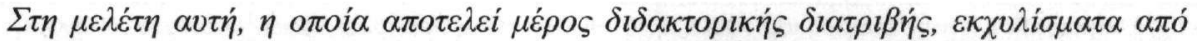

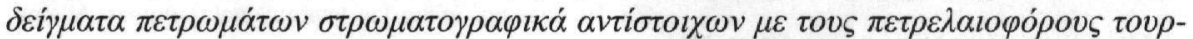

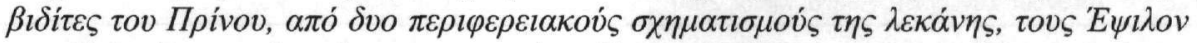

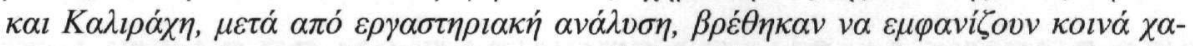

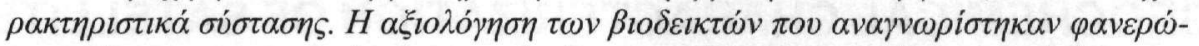

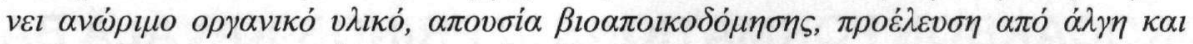

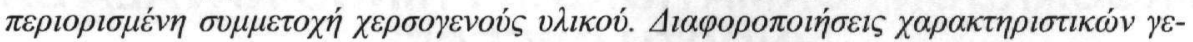

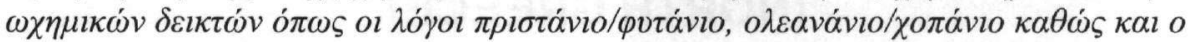

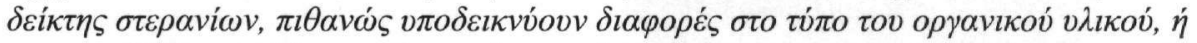

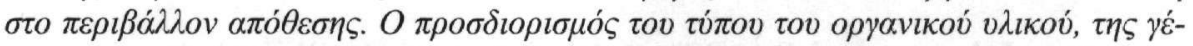

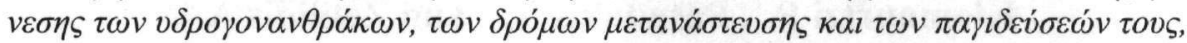

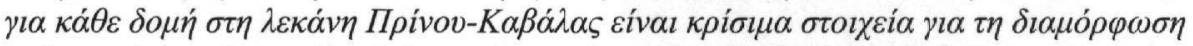

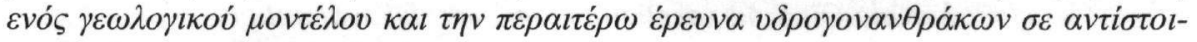

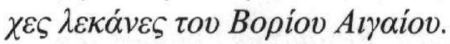

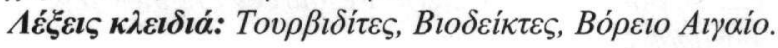

\section{Introduction}

Prinos-Kavala Basin is located at North Aegean Sea, between the mainland of Kavala area and Thassos island, as shown in Figure 1. The sedimentary basin is controlled by NE-SW and NW-SE faults. It is an elongated shaped basin, with NE-SW direction, asymmetrical regarding the sediments accumulation. The basin is filled with a thick section of deposits due to fast subsidence, starting at Miocene and continuing till nowadays. The total sediments thickness exceeds $5.8 \mathrm{~km}$, in the deepest parts of the basin.

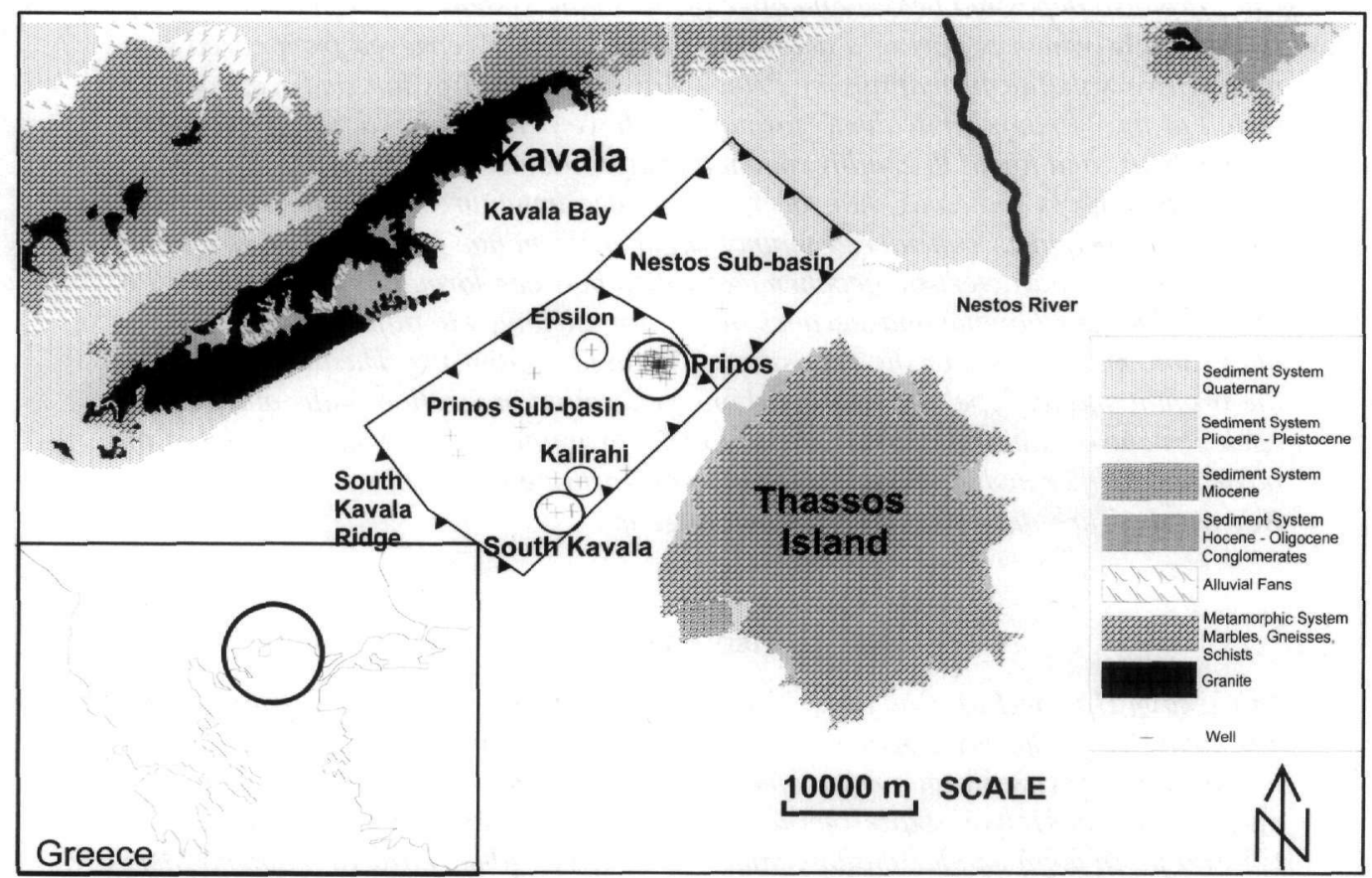

Figure 1 - Geological map showing the Prinos-Kavala Basin and the Prinos, Epsilon, Kalirahi and South Kavala structures 
Hydrocarbon exploration in North Aegean Sea led initially to the discovery of South Kavala gas field and Prinos oil field in Prinos-Kavala Basin. A number of geological and geochemical studies have been done, characterizing the source rock of "Prinos Oil" as waxy sapropelic oil prone kerogen, formed from aquatic higher plants in a strong reducing environment. The oil has a high aromatic and polar components concentration. The clay layers within the reservoir formation of Prinos field were recognized as potential source rocks of the oil (Georgakopoulos 1998).

The existence of other hydrocarbon reservoirs within the Prinos-Kavala basin was confirmed by later studies and drilling activities. Prinos North, Epsilon and Kalirahi structures were discovered at N, NW and SW of Prinos respectively. Epsilon has an anticline structure, proportional to Prinos anticline, as shown at the seismic sections in Figure 2, while Kalirahi anticline is controlled by a SE-NW direction fault. The present geochemical study has been made in order to investigate possible differences between the structures, regarding the organic matter. The biomarkers identified in the extracts provide important information about the depositional environment as well as the origin of the organic matter. A detailed sedimentological analysis is also being carried out, to corroborate the depositional environment.
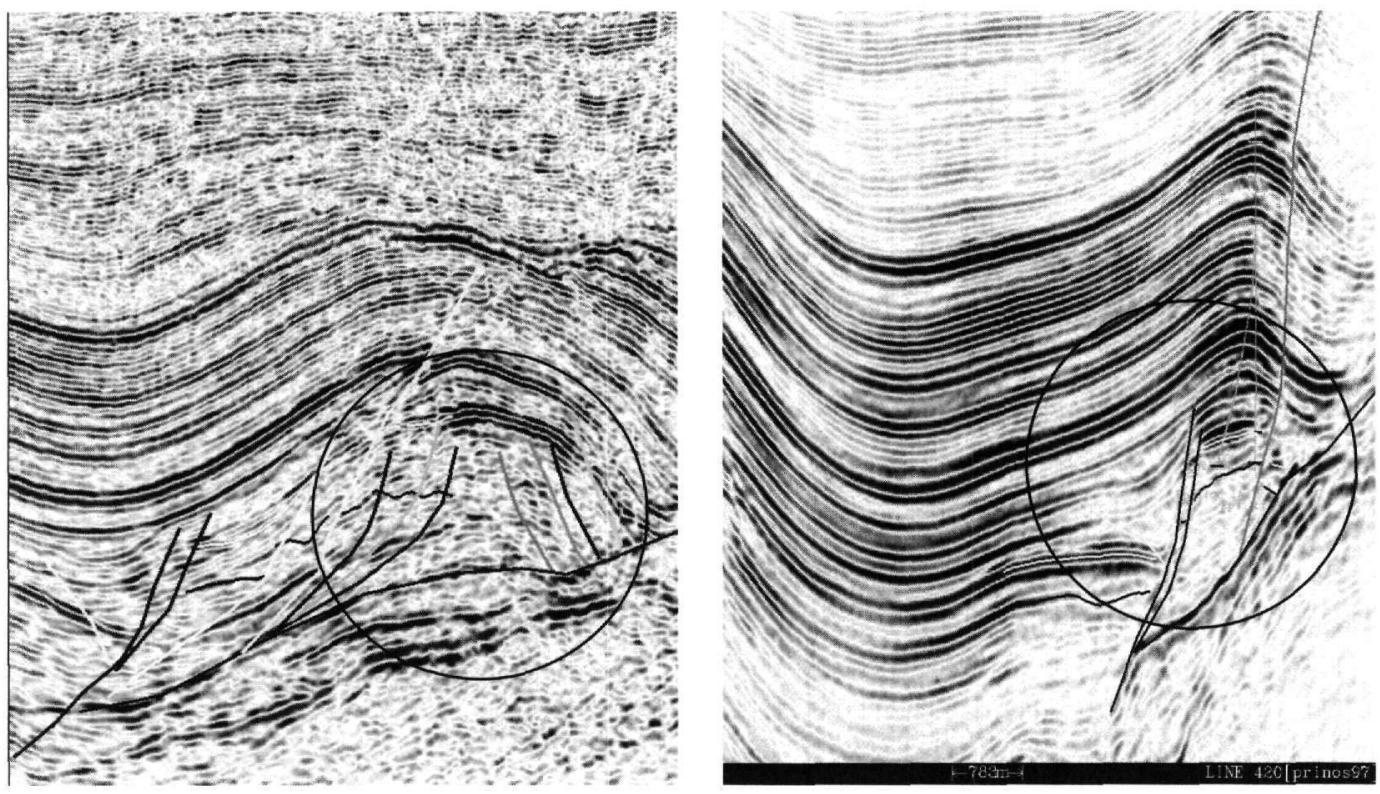

Figure 2 - Anticline Structures of Prinos (left) and Epsilon (right) formations with W-E and $\mathrm{S}-\mathrm{N}$ directions respectively

\section{Geological Setting}

Prinos-Kavala Basin is a tectonic basin located at the southern margin of the Rhodope Massif. It is situated in Kavala Bay in North Aegean Sea, surrounded by the mainland of Kavala area and Thassos Island. Its length is $38 \mathrm{~km}$, width $20 \mathrm{~km}$ and the main axis has NE-SW direction. The tectonism in the area started at Early Paleogene. Prinos-Kavala Basin is subdivided in two sub basins, the northern called Nestos sub basin, and the southern Prinos sub basin, separated by a topographic basement high (Proedrou 1986). NW-SE striking faults along the southern front of the basement high developed prograding sedimentation, and moved the sediments to the southwest deeper parts of Prinos basin, resulting in thick sediments accumulation.

Prinos basin development started during Miocene. At the first stage of sedimentation, the basin was open to the sea. South Kavala ridge rose progressively and isolated the basin, transforming it 
into a lagoon during Messinian. A similar basement high on the northeast of Thassos had the same effect on the basin. The isolation resulted in the deposition of seven evaporitic layers. (Proedrou 1986, Proedrou and Sidiropoulos 1992).

The first sediments deposited above the metamorphic basement (gneisses and marbles) were continental. Salt and anhydrite beds, inter-bedded with sandstones and marine shales deposited above them, and the Prinos turbidite system (reservoir) followed. This sequence is called the PreEvaporitic sequence, with an average thickness of $2000 \mathrm{~m}$. The existence of salt layers at the base of the basin assisted the sliding movements to the southwest deeper parts. Seven evaporitic layers interbedded with clastics, deposited during Upper Miocene (Messinian), overlay the PreEvaporitic sequence. The salt layers thickness exceeds $350 \mathrm{~m}$, whilst the whole sequence called the Evaporitic sequence, has an average thickness of $800 \mathrm{~m}$. The Post-Evaporitic sequence, consisting of sands and clays, deposited from Pliocene-Pleistocene till today. The average thickness of this sequence is $1800 \mathrm{~m}$ (Proedrou 1986, Proedrou and Papaconstantinou 2004). The stratigraphic column of Prinos sub-basin is shown in Figure 3, including the depths of formations drilled on Epsilon structure.

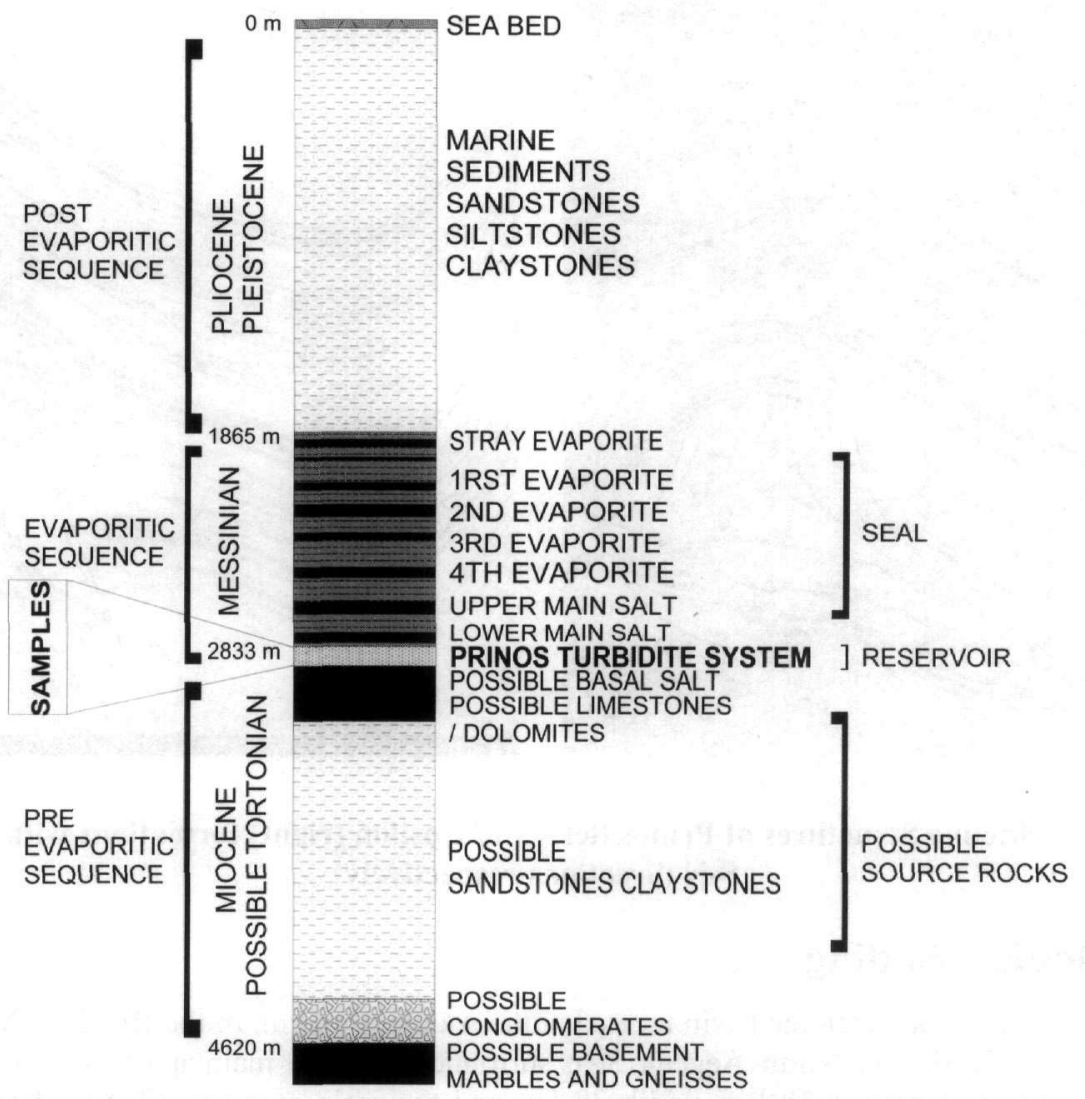

Figure 3 - Stratigraphic column of Prinos Sub-basin on Epsilon structure. As "possible" formations are the ones not drilled on Epsilon wells, but found on other wells within the ba$\sin$

Prinos Field structure is a rollover anticline. The average thickness of the turbidite system is $300 \mathrm{~m}$, at $2500 \mathrm{~m}$ TVD SS depth. Similar anticline structures are the Epsilon and Kalirahi structures. The Prinos equivalent turbidite system on Epsilon structure is found few hundred meters deeper, while on Kalirahi structure few hundred meters shallower. In both cases the formation thickness is significantly less compared to Prinos. The Post Evaporitic and the Evaporitic sequences were 
identified, as well as part of the Pre Evaporitic sequence. Hydrocarbon accumulation is found in the turbidite system, and the cap rock is a claystone layer 10-14 m thick, laid under the Evaporitic layers, similarly to Prinos.

\section{Materials and Methods}

Ten rock samples were collected from available cores retrieved from the turbidite formations from Epsilon and Kalirahi exploration wells. The samples were preserved in air-tight containers prior to the analysis, which was carried out in the Sedimentology and the PVT and Core analysis Laboratories of the University of Patras and the Technical University of Crete (Greece). Samples 1-7 were collected from the well E1As (Epsilon formation) and the samples 8-10 from the well K1 (Kalirahi formation). The routine organic geochemical procedures, used for sample analysis, are briefly described below.

Rock samples (about $100 \mathrm{~g}$ ) were ground to a fine powder $(<250 \mu \mathrm{m})$ and extracted in a Soxhlet apparatus, using the suite of solvents presented in Table 1. Soluble organic matter was obtained after solvent removal in a rotary evaporator and drying under $\mathrm{N}_{2}$. Aliquots of the extracts $(150 \mathrm{mg})$ dissolved in chloroform were further treated to remove sulfur by filtration though activated copper. Subsequently they were de-asphalted by adding an excess of n-pentane ( 40 volumes) and the resulting oil fractions (maltenes) were fractionated using open-column chromatography on silicaalumina mixture (1:3). Saturated hydrocarbons were recovered by eluting with n-pentane, aromatics with a 50:50 mixture of n-pentane- dichloromethane, resins with methanol and the remaining asphaltenes using chloroform.

The saturated fractions were analyzed by gas chromatography (GC) and gas chromatography-mass spectroscopy (GC-MS). A Perkin-Elmer 8700 FID chromatograph with a $30 \mathrm{mx} 0.32 \mathrm{mmx} 0.25 \mu \mathrm{m}$ column CP-Sil-5 CB-MS from Chrompack with helium as the mobile phase, temperature programmed from $60{ }^{\circ} \mathrm{C}$ to $300{ }^{\circ} \mathrm{C}$ at a rate of $6{ }^{\circ} \mathrm{C} / \mathrm{min}$ has been used. The samples $(1 \mu \mathrm{l})$ were injected dissolved in n-pentane (1/150) in a split-split less injector (split less mode) set at $250{ }^{\circ} \mathrm{C}$. The detector temperature was set at $300{ }^{\circ} \mathrm{C}$. The GC-MS analysis was carried out using a Fisson MD-800 system. The same column, as previously described in GC analysis was used, combined with a $5 \mathrm{~m}$ precolumn connected to an on-column injector. The $\mathrm{GC}$ oven was programmed from 45 ${ }^{0} \mathrm{C}$, to $145{ }^{\circ} \mathrm{C}$ at a rate of $10{ }^{\circ} \mathrm{C} / \mathrm{min}$ and to $250{ }^{\circ} \mathrm{C}$ at a rate of $4{ }^{\circ} \mathrm{C} / \mathrm{min}$. The MS was operated at 70 $\mathrm{eV}$ ionization voltage, with the interface and source temperatures set at $300{ }^{\circ} \mathrm{C}$ in full-scan $(50-500$ $\mathrm{m} / \mathrm{z}$ ). The terpanes and steranes ratios were calculated from the resulting $\mathrm{m} / \mathrm{z} 191,217$ and 218 mass fragmentograms. The peak identification in both GC and GC-MS analysis was performed based on the retention times of standard components as well as on the mass spectra.

\section{Results}

The rock samples employed in the current study, the depth they have been recovered from, the lithological description, the composition of the solvents mixtures used to obtain extracts and the determined organic matter content are presented in Table 1. The analytical results obtained by fractionating the extracts using n-pentane deasphalting and open-column chromatography are presented in. The calculated bulk composition of the extracts is also presented. For comparative purposes, the composition of two oils, ( $\mathrm{E}$ and $\mathrm{K}$ sample) produced during the flow tests of the wells under study is also included in (Pasadakis et al. 2005).

The rock extracts contain aromatic and polar components in high concentrations, which is a common characteristic for the oils of the whole Prinos - Kavala basin (Georgakopoulos 1998, Pasadakis et al. 2005). It can also be noticed that the rock extracts contain generally heavier and more polar components, compared to the respective oils. This can be attributed either to the storage conditions of the rock samples (evaporation and/or oxidation) or to possible adsorption of heavier components on the rock matrix. 
Table 1 - Sample depths-Solvents-Organic Matter Content

\begin{tabular}{|c|c|c|c|c|c|c|c|}
\hline Well & Sample & $\begin{array}{c}\text { Depth m, } \\
\text { TVD SS }\end{array}$ & Lithology & Toluene & Methanol & $\begin{array}{c}\text { Chloro- } \\
\text { form }\end{array}$ & $\begin{array}{c}\text { Extracted } \\
\text { Bitumens } \\
\text { (mg/g) }\end{array}$ \\
\hline \multirow{5}{*}{ E1 As } & 1 & 2832.87 & sandstone & $100 \%$ & & & 36.5 \\
\cline { 2 - 8 } & 2 & 2833.85 & sandstone & $100 \%$ & & & 66.3 \\
\cline { 2 - 8 } & 3 & 2834.67 & sandstone & $100 \%$ & & & 53.0 \\
\cline { 2 - 8 } & 5 & 2835.02 & sandstone & $86 \%$ & $14 \%$ & & 30.2 \\
\cline { 2 - 8 } & 6 & 2836.03 & sandstone & $100 \%$ & & & 16.1 \\
\hline \multirow{3}{*}{ K1 } & 7 & 2836.48 & sandstone & $100 \%$ & & & 9.5 \\
\cline { 2 - 8 } & 8 & 2221.06 & Silt clay stone & $75 \%$ & $12,5 \%$ & $12,5 \%$ & 7.4 \\
\hline & 10 & 2288.36 & Clay stone & $50 \%$ & $25 \%$ & $25 \%$ & 13.2 \\
\hline
\end{tabular}

The analysis of the bulk compositional data indicates that a clear correlation between the compositions of the extracts vs. depth of the rock samples does not exist. Given that the observed compositional differences within the samples are significantly greater than the repeatability of the experimental procedure ( $2 \%$ absolute error), it can be concluded that the organic matter is distributed in the reservoir in a rather non-homogeneous way. The possibility that the compositional differences may be related, partly at least, to the chemical nature of the solvents used to extract bitumens from the rock samples should be further examined.

The saturated fraction gas chromatograms of the samples under study are shown in Figure 4 and Figure 5, and the respective common geochemical indices calculated from these analytical data are presented in Table 3.

The chromatograms show a clear predominance of the even carbon number n-alkanes with the phytane being the component exhibiting the highest concentration in the saturated fraction. A similar even predominance of $n$-alkanes has been reported for rock extracts derived from the Prinos reservoir, located in the same basin (Georgakopoulos 1998). The presence of $n$-alkanes with long aliphatic chains $\left(>\mathrm{C}_{18}\right)$ has been recognized as indication of higher plants input in marine or terrestrial environment. The general distribution of $\mathrm{n}$-alkanes is rather unimodal, with the exception of the sample 6 , where a rather bimodal distribution around $\mathrm{C}_{18}$ and $\mathrm{C}_{28}$ can be observed.

The Carbon Preference Index (CPI) calculated for the $\mathrm{C}_{24}-\mathrm{C}_{34}$ n-alkanes range (Bray and Evans 1961) exhibit values of the same magnitude as those previously reported for the Prinos reservoir. These values can attributed to carbonate or to evaporitic environments and they agree with the low $\mathrm{Pr} / \mathrm{Ph}$ ratios of the extracts.

The calculated $\mathrm{Pr} / \mathrm{Ph}$ ratios for the extracts from the two formations exhibit values of different magnitude. This ratio is considered characteristic for the redox potential in the depositional environment (Didyk et al. 1978). $\mathrm{Pr} / \mathrm{Ph}$ values less than one, as in the current study, indicate anoxic deposition, particularly when oils exhibit high sulfur content and they have been associated with the even predominance of the n-alkanes distribution. It should be noticed that the $\mathrm{Pr} / \mathrm{Ph}$ values of Epsilon and Kalirahi formation are lower than the reported ones for the Prinos reservoir(0.16-0.18) (Georgakopoulos 1998). Therefore, it can be concluded that the oils from separate formations in Prinos-Kavala basin can be successfully distinguished based on the $\mathrm{Pr} / \mathrm{Ph}$ ratio, probably due to the different redox conditions occurring within the basin. 


\begin{tabular}{|c|c|c|c|c|c|c|c|c|c|c|c|c|c|c|}
\hline \multirow{6}{*}{ 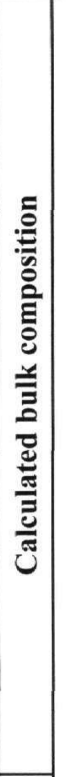 } & & $\begin{array}{l}0 \\
\mathscr{n} \\
Z\end{array}$ & 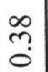 & 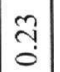 & $\begin{array}{l}0 \\
0 \\
0\end{array}$ & $\stackrel{0}{0}$ & 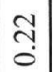 & $\begin{array}{l}0 \\
\tilde{n} \\
0\end{array}$ & 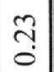 & $\begin{array}{l}\infty \\
n \\
0\end{array}$ & $\begin{array}{l}\infty \\
n \\
0\end{array}$ & $\stackrel{\text { If }}{\circ}$ & $\stackrel{\mathcal{Y}}{\stackrel{2}{0}}$ & $\stackrel{g}{\stackrel{g}{0}}$ \\
\hline & & $\underset{\simeq}{\mathbb{2}}$ & $\begin{array}{l}\tilde{\sigma} \\
0 \\
0\end{array}$ & $\begin{array}{l}\hat{\sigma} \\
0 \\
0\end{array}$ & $\begin{array}{l}+ \\
\infty \\
0\end{array}$ & $\begin{array}{l}R \\
0 \\
0\end{array}$ & $\begin{array}{l}\infty \\
\stackrel{\infty}{0}\end{array}$ & $\begin{array}{l}\stackrel{2}{0} \\
0\end{array}$ & 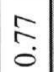 & $\begin{array}{l}\sigma \\
0 \\
0\end{array}$ & $\stackrel{\text { I }}{\circ}$ & 告 & $\begin{array}{l}\infty \\
n \\
0 \\
0\end{array}$ & $\bar{c}$ \\
\hline & & 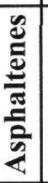 & 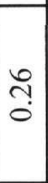 & $\stackrel{n}{0}$ & $\begin{array}{l}8 \\
0 \\
0\end{array}$ & $\overrightarrow{\widetilde{o}}$ & $\stackrel{7}{\rightleftarrows}$ & $\mid \begin{array}{c}\infty \\
-1 \\
0\end{array}$ & $\stackrel{0}{0}$ & 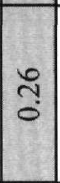 & \begin{tabular}{l}
0 \\
\hdashline \\
0
\end{tabular} & $\stackrel{\infty}{m}$ & ? & $\stackrel{0}{?}$ \\
\hline & & $\stackrel{\mathscr{E}}{\stackrel{\mathscr{E}}{\mathscr{Z}}}$ & $=$ & $\begin{array}{l}\infty \\
0 \\
0 \\
0\end{array}$ & $\hat{0}$ & $\begin{array}{l}8 \\
0 \\
0\end{array}$ & $\stackrel{0}{\circ}$ & $\frac{1}{0}$ & $\hat{0}$ & $\overline{0}$ & $\stackrel{\infty}{\stackrel{0}{0}}$ & $\stackrel{5}{\circ}$ & $\stackrel{0}{\circ}$ & $\frac{m}{0}$ \\
\hline & & 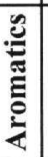 & ?̊? & $\begin{array}{c}\tilde{1} \\
\tilde{0} \\
0\end{array}$ & $\underset{\overbrace{}}{\tilde{o}}$ & $\vec{m}$ & 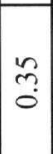 & 苦 & ஸै & @̊ & $\stackrel{\overbrace{}}{\sim}$ & 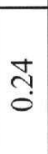 & i̊ & $\stackrel{0}{0}$ \\
\hline & & 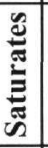 & $\tilde{n}$ & $\stackrel{1}{1}$ & $\begin{array}{l}\tilde{b} \\
\stackrel{0}{0}\end{array}$ & ڤి & $\stackrel{\leftrightarrow}{\leftrightarrow}$ & 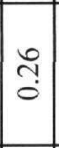 & 官. & $\stackrel{m}{0}$ & $\stackrel{n}{\circ}$ & $\vec{n}$ & กี & $\frac{ \pm}{0}$ \\
\hline \multirow{5}{*}{ 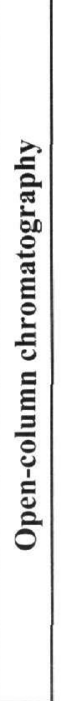 } & \multirow{5}{*}{ 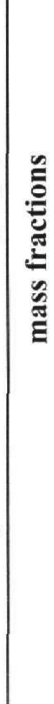 } & 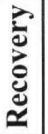 & ڤ̊ & $\stackrel{0}{\circ}$ & $\begin{array}{l}\infty \\
\stackrel{0}{0}\end{array}$ & $\stackrel{\circ}{\circ}$ & $\stackrel{\Omega}{0}$ & $\stackrel{\circ}{\circ}$ & $\hat{\sigma}$ & g. & $\hat{a}$ & $\stackrel{2}{\circ}$ & $\stackrel{\circ}{\circ}$ & $\stackrel{8}{8}$ \\
\hline & & 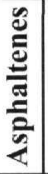 & $\frac{0}{0}$ & \begin{tabular}{|l|}
0 \\
0 \\
0 \\
0
\end{tabular} & $\begin{array}{l}0 \\
0\end{array}$ & $\stackrel{\sim}{\stackrel{0}{0}}$ & $\begin{array}{l}\infty \\
0 \\
0 \\
0\end{array}$ & $\overrightarrow{0}$ & ga & $\frac{0}{0}$ & $\vec{m}$ & $\stackrel{\overbrace{}}{0}$ & $\bar{\jmath}$ & $\underset{0}{+}$ \\
\hline & & 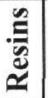 & $\stackrel{m}{\circ}$ & $\begin{array}{l}\infty \\
0 \\
0 \\
0\end{array}$ & $\stackrel{0}{0}$ & $\stackrel{0}{\circ}$ & $=$ & $\stackrel{m}{\circ}$ & \begin{tabular}{|l|}
$\infty$ \\
0 \\
0 \\
0
\end{tabular} & $\frac{m}{0}$ & $\exists$ & $\begin{array}{l}\infty \\
\stackrel{0}{0}\end{array}$ & $\begin{array}{l}\infty \\
0 \\
0\end{array}$ & $\frac{2}{0}$ \\
\hline & & 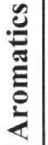 & $\stackrel{+}{?}$ & 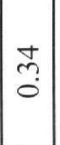 & ָุ & $\stackrel{+}{m}$ & $\begin{array}{l}\infty \\
m \\
0 \\
0\end{array}$ & 守 & $\stackrel{m}{0}$ & ঙे & $\begin{array}{l}0 \\
\text { ?! } \\
0\end{array}$ & ڤి & ?̊ & กี \\
\hline & & 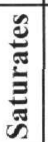 & $\hat{n}$ & $\stackrel{r}{\stackrel{f}{\sigma}}$ & $\begin{array}{l}\mathcal{G} \\
\stackrel{0}{0}\end{array}$ & $\stackrel{\Re}{\stackrel{0}{0}}$ & 吕 & $\begin{array}{l}\infty \\
\stackrel{1}{0} \\
\stackrel{2}{*}\end{array}$ & 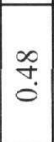 & $\hat{n}$ & ঙ̊ & $\stackrel{\infty}{\overbrace{0}}$ & $\stackrel{\infty}{\infty}$ & $\frac{m}{0}$ \\
\hline \multirow{4}{*}{\multicolumn{2}{|c|}{ 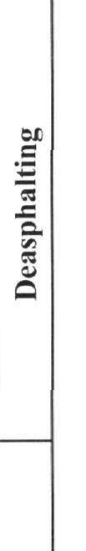 }} & 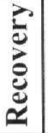 & $\begin{array}{l}\infty \\
\stackrel{0}{0}\end{array}$ & $\dot{\sigma}$ & $\stackrel{a}{\circ}$ & $\hat{\sigma}$ & aे & $\begin{array}{l}\infty \\
\stackrel{0}{0}\end{array}$ & $\stackrel{8}{0}$ & $\begin{array}{l}\infty \\
0 \\
0\end{array}$ & $\hat{o}$ & ڤे & $\stackrel{8}{8}$ & రె \\
\hline & & 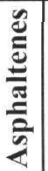 & $\stackrel{1}{\stackrel{0}{0}}$ & 它 & $\stackrel{5}{0}$ & $\stackrel{0}{0}$ & $\begin{array}{l}n \\
0 \\
0 \\
0\end{array}$ & $\stackrel{\Xi}{0}$ & $\begin{array}{l}5 \\
0 \\
0\end{array}$ & $\frac{1}{0}$ & $\begin{array}{l}\stackrel{\circ}{\sim} \\
\stackrel{0}{\sigma}\end{array}$ & $\frac{a}{0}$ & $\frac{\infty}{0}$ & ָ̦ \\
\hline & & 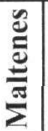 & $\begin{array}{l}\infty \\
\infty \\
0 \\
0\end{array}$ & $\tilde{\alpha}$ & $\hat{\sigma}$ & $\stackrel{8}{\circ}$ & $\begin{array}{l}n \\
a \\
0\end{array}$ & $\stackrel{2}{0}$ & $\hat{\varrho}$ & $\begin{array}{l}\infty \\
\infty \\
0 \\
0\end{array}$ & $\stackrel{+}{\stackrel{0}{0}}$ & $\begin{array}{l}\infty \\
\stackrel{0}{0}\end{array}$ & $\begin{array}{l}1 \\
\infty \\
0 \\
0\end{array}$ & $\stackrel{a}{\stackrel{2}{0}}$ \\
\hline & & 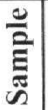 & - & $N$ & $m$ & $\forall$ & $n$ & 0 & $r$ & पi & $\infty$ & $a$ & 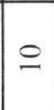 & $\underline{\overline{0}}$ \\
\hline
\end{tabular}



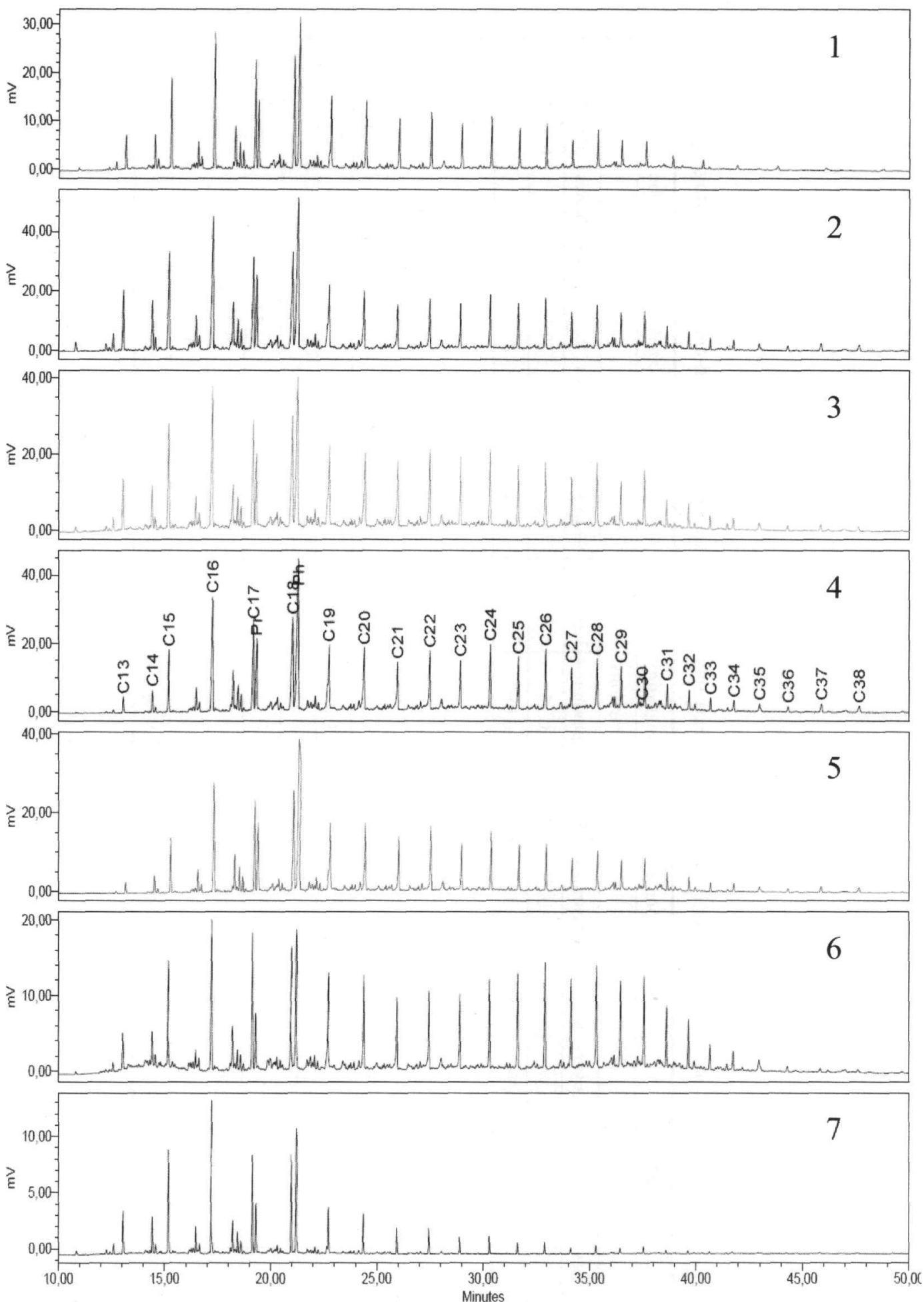

Figure 4 - The gas chromatograms of saturated fractions from the Epsilon formation samples 

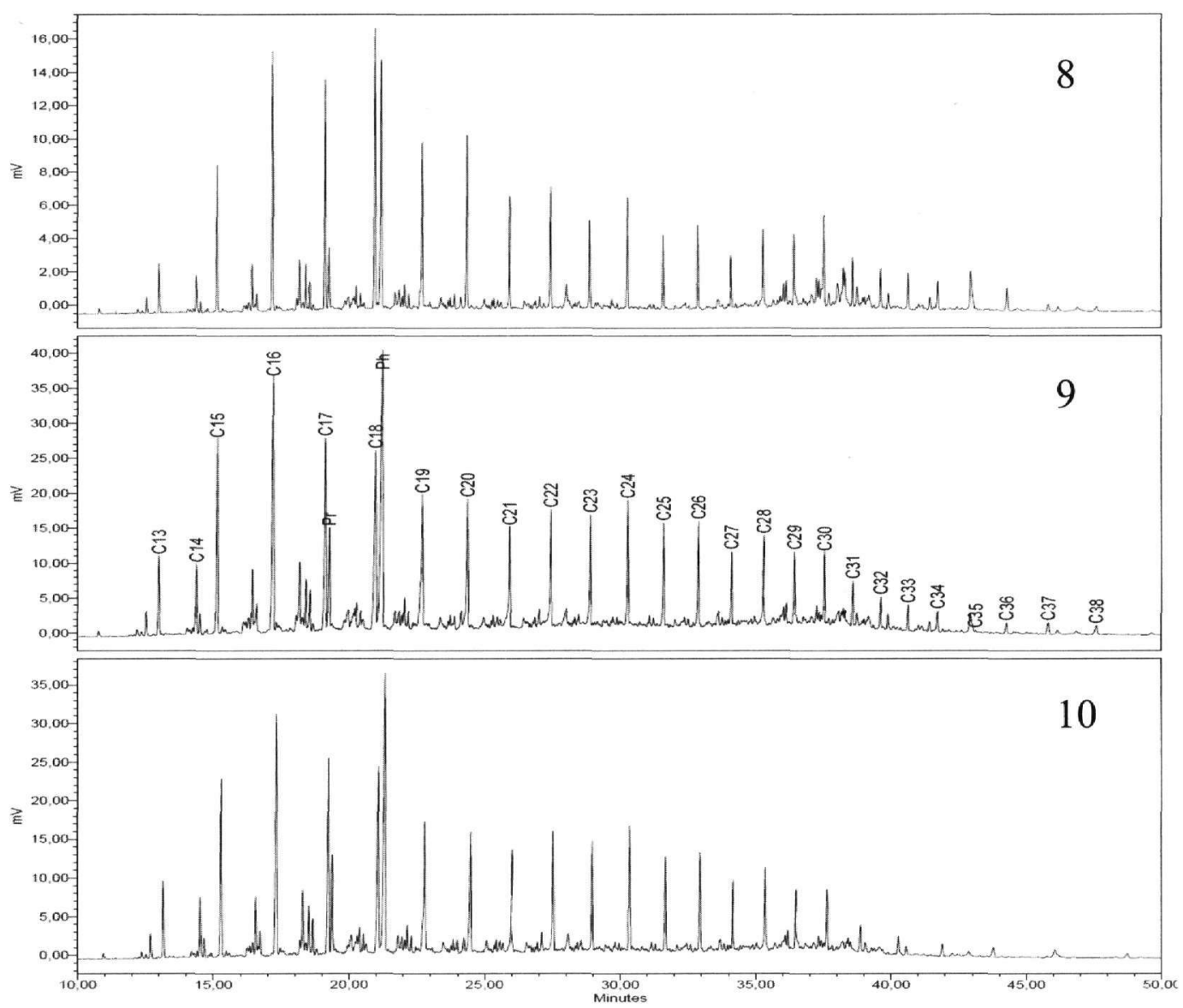

Figure 5 - The gas chromatograms of saturated fractions from the Kalirahi formation samples

Table 3 - Geochemical indices calculated from the saturated fractions GC analysis

\begin{tabular}{|c|c|c|c|c|c|c|c|c|c|c|}
\hline $\begin{array}{c}\text { Index/ } \\
\text { Sample No }\end{array}$ & $\mathbf{1}$ & $\mathbf{2}$ & $\mathbf{3}$ & $\mathbf{4}$ & $\mathbf{5}$ & $\mathbf{6}$ & $\mathbf{7}$ & $\mathbf{8}$ & $\mathbf{9}$ & $\mathbf{1 0}$ \\
\hline $\mathrm{Pr} / \mathrm{Ph}$ & 0,33 & 0,33 & 0,32 & 0,31 & 0,30 & 0,32 & 0,38 & 0,21 & 0,25 & 0,24 \\
\hline $\mathrm{Pr} / \mathrm{C}_{17}$ & 0,65 & 0,72 & 0,59 & 0,73 & 0,74 & 0,42 & 0,62 & 0,32 & 0,47 & 0,47 \\
\hline $\mathrm{Ph} / \mathrm{C}_{18}$ & 1,66 & 1,79 & 1,51 & 1,81 & 1,87 & 1,29 & 1,66 & 1,08 & 1,74 & 1,80 \\
\hline $\mathrm{CPI}$ & 0,80 & 0,82 & 0,76 & 0,78 & 0,75 & 0,90 & 0,77 & 0,81 & 0,87 & 0,87 \\
\hline
\end{tabular}

The calculated isoprenoids to n-alkanes ratios $\mathrm{Pr} / \mathrm{C}_{17}$ and $\mathrm{Ph} / \mathrm{C}_{18}$, exhibit greater variability, compared to the $\mathrm{Pr} / \mathrm{Ph}$, possibly due to different thermal maturity or biodegradation levels. $\operatorname{Pr} / \mathrm{C}_{17}$ ratios for the Epsilon formation are of the same magnitude as previously reported for the Prinos reservoir, while Kalirahi formation exhibits lower values. The calculated $\mathrm{Ph} / \mathrm{C}_{18}$ values are more or less of the same magnitude for both formations with the exception of sample 8 , which shows a distinct low value compared to the other samples. Finally the absence of the characteristic "hump" of the unresolved complex mixture (UCM) in the saturated fraction gas chromatograms indicates that the Epsilon and Kalirahi extracts are not biodegraded. 
Concluding from the gas chromatographic analysis of the saturated fractions, the oils of the two formations in the present study as well as the previously studied Prinos reservoir have been produced from organic matter of similar composition. The observed distinct compositional features can be attributed to differences in the depositional environments.

Characteristic m/z 191 and 217 fragmentograms from the GC-MS analysis of the Kalirahi extracts are shown in Figure 6. The calculated common biomarker indices are presented in Table 4.

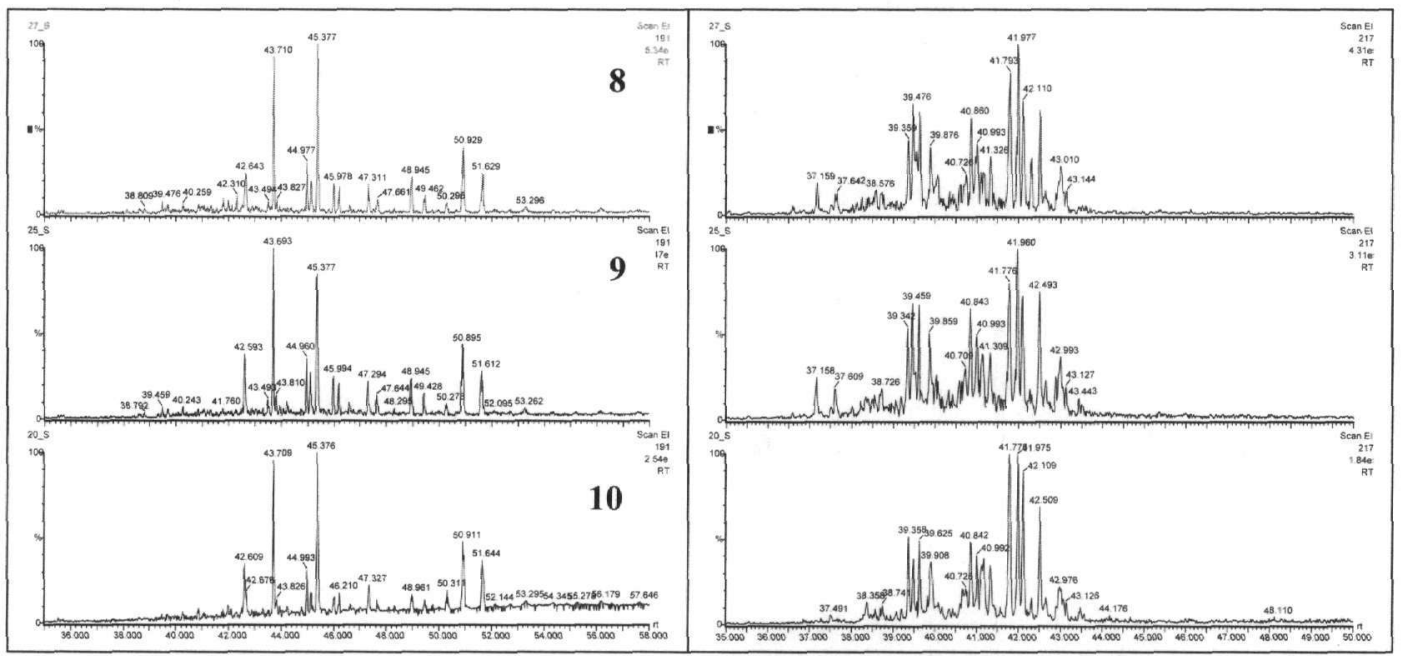

Figure 6 - The m/z 191 and m/z 217 fragmentograms of the saturated fraction from Kalirahi formation extracts

The main findings from the analysis of the biomarker traces $\mathrm{m} / \mathrm{z} 191$ and $\mathrm{m} / \mathrm{z} 217$ fragmentograms can be summarized as follows:

The homohopane index, calculated as the ratio $\mathrm{C}_{35} /\left(\mathrm{C}_{31}\right.$ to $\left.\mathrm{C}_{35}\right)$ homohopanes, is considered as an indicator of the redox potential of marine sediments during diagenesis and it is affected by the thermal maturity (Peters and Moldowan 1991). High $\mathrm{C}_{35}$ homohopanes content, such as the case in the current study, is associated with marine carbonates or evaporites (Clark and Philp 1989) or as an indicator of highly reducing marine conditions during deposition.

Table 4 - Calculated geochemical indices

\begin{tabular}{|c|c|c|c|c|c|c|c|c|}
\hline Index/ Sample No & $\mathbf{1}$ & $\mathbf{2}$ & $\mathbf{3}$ & $\mathbf{4}$ & $\mathbf{6}$ & $\mathbf{8}$ & $\mathbf{9}$ & $\mathbf{1 0}$ \\
\hline oleanane index & 0,20 & 0,23 & 0,21 & 0,24 & 0,16 & 0,05 & 0,07 & 0,10 \\
\hline gammacerane index & 1,10 & 0,96 & 2,52 & 0,90 & 1,36 & 1,04 & 1,09 & 0,84 \\
\hline moretane/hopane & 0,10 & 0,09 & 0,07 & 0,07 & 0,09 & 0,06 & 0,03 & 0,08 \\
\hline homohopane index & 28,3 & 26,7 & 50,1 & 23,7 & 34,5 & 40,8 & 31,3 & 29,1 \\
\hline $\mathbf{C}_{27}$ steranes & 37 & 38 & 37 & 38 & 35 & 25 & 30 & 31 \\
\hline $\mathbf{C}_{\mathbf{2 8}}$ steranes & 24 & 24 & 23 & 24 & 25 & 21 & 23 & 23 \\
\hline $\mathbf{C}_{\mathbf{2 9}}$ steranes & 39 & 38 & 40 & 38 & 40 & 54 & 48 & 45 \\
\hline
\end{tabular}

The Ts/Tm index, which is considered characteristic for the maturation level of the oil samples, could not be calculated due to the low abundance of the Tm component. Since high values of this index indicate mature oils the studied samples can be characterized as immature. This finding is in agreement with the observed high NSO content as well as the low ratio between saturates and aromatics. 
The calculated high gamacerane index, which is considered as indicator of the salinity in the depositional environment is in agreement with the low $\mathrm{Pr} / \mathrm{Ph}$ values reported above. The sample No 3 exhibit a significantly greater value compared to the rest of the samples. It is significant that the same sample exhibits also a high value of the homohopane index.

The presence of the oleanane in the extracts is an indication of higher plant material involved in the source organic matter. The observed difference in the oleanane index values (oleanane/ $\mathrm{C}_{30}$ hopane) between the samples from Epsilon and Kalirahi formations indicates higher terrestrial input for the former.

The relative abundance of $\mathrm{C}_{27}, \mathrm{C}_{28}$ and $\mathrm{C}_{29}$ steranes, which has been reported as indicative for the origin of the source organic matter, shows that the oils are produced from marine algae as the $\mathrm{C}_{27}$ steranes dominate. The relative high concentration of the $\mathrm{C}_{29}$ steranes may be attributed to terrestrial organic input. The observed differences in $\mathrm{C}_{27}, \mathrm{C}_{28}, \mathrm{C}_{29}$ steranes between Epsilon and Kalirahi formations is considered as an indication that the two oils are produced from different source rocks or from different organic facies within the same source rock.

\section{Conclusions}

The analyzed extracts of the two formations, Epsilon and Kalirahi, located in Prinos-Kavala Basin, are compositionally closely related. The oils are immature and have not been altered by biodegradation. Some of the main geochemical features determined are the even to odd predominance, the predominance of the phytane over pristane, the high NSO content, the higher concentration of aromatics compared to the saturates and the high concentration of steranes and terpanes. All these findings suggest that the oils have been generated from sapropelic kerogen deposited in a strongly reducing environment. The origin of the organic matter can be characterized as algal, with additional terrestrial input.

Apart from the general compositional correlation however, variations on ratios of $\mathrm{Pr} / \mathrm{Ph}, \mathrm{Ts} / \mathrm{Tm}$ and oleanane/hopane are identified among the formations. Hence, further investigation on satellite formations within the basin, such as Epsilon and Kalirahi, continues in a doctorate thesis, in order to reveal the controlling factors that cause these changes, and probably relate to differences on depositional environments and organic mater source(s).

\section{Acknowledgments}

The authors wish to acknowledge Kavala Oil S. A. company for making the cores available and permitting the publication of this study. The authors also wish to acknowledge the General Secretariat for Research and Technology of the Ministry of Development and the European Office of Regional Development of the European Commission for partially financing this project.

\section{References}

Bray, E.E., and Evans, E. D., 1961. Distribution of n-paraffins as a clue to recognition of source beds, Ceochimica et Cosmochimica Acta, 22, 2-15.

Clark, L.P., and Philp, S.W., 1989. Geochemical characterization of evaporate and carbonate depositional environments and correlation of associated crude oils in the black Creek Basin. Alberta, Canadian Petroleum Geologist Bulletin, 37, 401-416.

Didyk, A., Simoneit, B.R.T., Brassell, S.C., and Englinton, G., 1978. Organic geochemical indication of paleoenvironmental conditions of sendimentation, Nature, 272, 216-222.

Georgakopoulos, A., 1998. Lithology and stratigraphy of the Neogene Prinos-Kavala basin. North Greece, Geological Society of Greece. Sp. Publ., No 9, 79-84. 
Georgakopoulos, A., 1998. Organic geochemical study of Greek oil source rocks, Conference and exhibition, modern exploration and improved oil and gas recovery methods, 208-213.

Georgakopoulos, A., 1998. Study of source rocks of the petroliferous Prinos-Kavala basin using organic geochemical methods, Proc. of the XXXII/3 Geological Society of Greece, Patra, May, 325-333.

Pasadakis, N., Koutsotheodorou, E., Manoutsoglou, E., Papaconstantinou, C., Kiomourtzi, P., and Zelilidis, A., 2005. A comparative study of oils from Kavala Basin using biomarkers analysis, $2^{\text {nd }}$ Conference of the Committee of Economical Geology, Mineralogy and Geochemistry of the Geological Society of Greece, Thessaloniki, October, 309-317.

Peters, K.E., and Moldowan, J.M., 1991. Effect of source. thermal maturity and biodegradation on the distribution and isomerization of homohopanes in petroleum, Organic Geochemistry,. $17,47-61$.

Proedrou, P., and Papaconstantinou, P., 2004. Prinos Basin - A model for exploration, Proc. of the XXXVI Geological Society of Greece, Thessaloniki, April, 327-333.

Proedrou, P., and Sidiropoulos, T., 1992. Prinos Field-Greece. Aegean basin. Structural Traps. Treatise of petroleum Geology, Atlas of oil and gas field, VI. AAPG. 275-291.

Proedrou, P., 1986. New age determination of the Prinos Basin, Proc. of the XX/2 Geological Society of Greece, May, 141-147. 